\title{
Review
}

\section{The VHL tumor suppressor and HIF: insights from genetic studies in mice}

\author{
PP Kapitsinou ${ }^{1}$ and VH Haase ${ }^{\star, 1}$
}

The von Hippel-Lindau tumor suppressor gene product, $\mathrm{pVHL}$, functions as the substrate recognition component of an E3-ubiquitin ligase, which targets the oxygen-sensitive $\alpha$-subunit of hypoxia-inducible factor (HIF) for rapid proteasomal degradation under normoxic conditions and as such plays a central role in molecular oxygen sensing. Mutations in pVHL can be found in familial and sporadic clear cell carcinomas of the kidney, hemangioblastomas of the retina and central nervous system, and pheochromocytomas, underscoring its gatekeeper function in the pathogenesis of these tumors. Tissue-specific gene targeting of $\mathrm{VHL}$ in mice has demonstrated that efficient execution of PVHL-mediated HIF proteolysis under normoxia is fundamentally important for survival, proliferation, differentiation and normal physiology of many cell types, and has provided novel insights into the biological function of individual HIF transcription factors. In this review, we discuss the role of HIF in the development of the VHL phenotype.

Cell Death and Differentiation (2008) 15, 650-659; doi:10.1038/sj.cdd.4402313; published online 25 January 2008

Germ-line mutations in the von Hippel-Lindau tumor (VHL) suppressor can be found in patients with VHL disease, a rare familial tumor syndrome characterized by the development of highly vascularized tumors in multiple organs. Major clinical manifestations of $\mathrm{VHL}$ disease include hemangioblastomas of the retina and central nervous system (CNS), renal cysts and renal cell carcinoma of the clear cell type (CC-RCC), pancreatic cysts and tumors, as well as pheochromocytomas. ${ }^{1}$ The VHL tumor suppressor is also mutated in the majority of sporadic CC-RCCs, ${ }^{2}$ highlighting its critical and central role in the regulation of cell growth and differentiation of epithelial kidney cells. Although the molecular function of the VHL gene product, pVHL, was initially not known when it was first identified by positional cloning in $1993,{ }^{3}$ observations that oxygen-dependent regulation of hypoxia-inducible genes was lost in $V H L$-deficient cell lines suggested a role for $\mathrm{pVHL}$ in oxygen sensing. ${ }^{4-6}$ In a seminal paper, Maxwell et al. ${ }^{7}$ showed that $\mathrm{PVHL}$ was critical for targeting the $\alpha$-subunit of hypoxia-inducible factor (HIF) for oxygen-dependent proteolysis, thus providing a direct molecular link between VHLassociated tumorigenesis and oxygen sensing via HIF. HIFs belong to the PAS (Per-arylhydrocarbon receptor nuclear translocator (ARNT)-Sim) family of basic helix-loop-helix (bHLH) transcription factors and bind DNA as heterodimers. They consist of an oxygen-sensitive $\alpha$-subunit and a constitutively expressed $\beta$-subunit, also known as ARNT or HIF- $\beta$. $\mathrm{pVHL}$ associates with the elongins $\mathrm{B}$ and $\mathrm{C}$, cullin2 and $\mathrm{Rbx}^{8-12}$ and functions as the substrate recognition component of an
E3-ubiquitin ligase that ubiquitylates HIF- $\alpha .{ }^{13-19}$ All three HIF $\alpha$-subunits, HIF- $1 \alpha$, HIF- $2 \alpha$ and HIF- $3 \alpha$ interact with $\mathrm{PVHL} .{ }^{7,20}$ This $\mathrm{pVHL}-\mathrm{HIF}-\alpha$ interaction is highly conserved between species, requires iron- and oxygen-dependent hydroxylation of specific proline residues (Pro402 and Pro564 in human HIF-1 $\alpha$; Pro405 and Pro531 in human HIF-2 $\alpha$ ) within the oxygen-dependent degradation domain of HIF- $\alpha$ and is necessary for the execution of HIF proteolysis under normoxia. ${ }^{21-27}$ Therefore, absence of $\mathrm{pVHL}$ results in HIF- $\alpha$ stabilization, increased HIF transcriptional activity and upregulation of HIF target genes, such as vascular endothelial growth factor (VEGF), glucose transporter 1 and erythropoietin (EPO) irrespective of oxygen levels.

To understand the role of PVHL-mediated HIF proteolysis in normal tissue physiology, tumorigenesis and during development, we have used cell-type-specific gene targeting based on Cre recombinase (Cre)/loxP-mediated recombination. In this review, we will summarize the findings from a variety of developmental and physiological studies in conditional VHL and HIF knockout mice and provide insights into the biological function of individual HIF transcription factors in a VHLdeficient background.

\section{Normoxic Stabilization of HIF- $\alpha$ in VHL-Deficient Tissues}

$\mathrm{pVHL}$ is a master regulator of HIF- $\alpha$ proteolysis, and genetic inactivation of the $V H L$ gene results in HIF- $\alpha$ stabilization and increased activity of HIF transcription factors. The most

\footnotetext{
${ }^{1}$ Department of Medicine, University of Pennsylvania School of Medicine, Philadelphia, PA, USA

*Corresponding author: VH Haase, Department of Medicine, University of Pennsylvania School of Medicine, 727 CRB, 415 Curie Boulevard, Philadelphia, PA 191046144, USA. Tel: 215573 1830; Fax: 215746 5831; E-mail: vhaase@mail.med.upenn.edu

Keywords: von Hippel-Lindau (VHL) tumor suppressor; hypoxia-inducible factor (HIF); conditional knockout mice; renal cell cancer; hemangiomas; vascular tumors Abbreviations: ARNT, arylhydrocarbon receptor nuclear translocator; CC-RCC, renal cell carcinoma of the clear cell type; Cre, Cre recombinase; EPO, erythropoietin; HIF, hypoxia-inducible factor; PEPCK, phosphoenolpyruvate carboxykinase; PHD protein, prolyl-hydroxylase domain protein; pVHL, von Hippel-Lindau protein; VEGF, vascular endothelial growth factor; VHL, von Hippel-Lindau; THP, Tamm-Horsfall protein

Received 15.11.07; revised 18.12.07; accepted 19.12.07; Edited by N Chandel; published online 25.1.08
} 
extensively studied PAS family transcription factors that are targeted by $\mathrm{pVHL}$ are HIF-1 and HIF-2 (here collectively referred to as HIF). HIFs regulate gene expression through interaction with hypoxia response elements, specific DNA recognition sequences that are located in hypoxia enhancer regulatory regions and bind HIF heterodimers. ${ }^{28} \mathrm{HIF}-1$ and HIF-2 have distinct cell type- and tissue-specific biological functions and only overlap partially with regard to their target genes. For example, genes encoding glycolytic enzymes appear to be predominantly controlled by HIF-1, ${ }^{29}$ whereas HIF-2 appears to be the main regulator of VEGF and EPO in tissues that express both HIF-1 and HIF-2. ${ }^{30-33}$ Target gene preference may be the result of tissue-specific interactions with other nuclear factors, differential interactions with transcriptional cofactors or a reflection of tissue- and celltype-dependent differences in the ratios of $\mathrm{HIF}-\alpha$ protein levels (for a review on this topic see Wenger et al. ${ }^{28}$ ).

In addition to heterodimerization with HIF- $\beta$, which results in the formation of a bHLH transcription factor that mediates the canonical hypoxia response, stabilization of HIF- $\alpha$ subunits has also been shown to regulate biological processes through functional interaction with other non-PAS domain proteins. These include, among others, tumor suppressor protein p53 and the c-Myc proto-oncogene. ${ }^{34-36}$ A more recent example is the ability of HIF- $1 \alpha$ to associate with the intracellular domain of Notch (Notch ICD), thereby increasing the expression of Notch-target genes, such as Hey and Hes. ${ }^{37}$ This and other HIF- $\alpha$ /non-PAS domain protein interactions have to be considered when interpreting experimental phenotypes that result from $V H L$ gene deletion in the laboratory mouse.

A second hypoxic switch operates in the carboxy-terminal transactivation domain of HIF- $\alpha$ with the hydroxylation of an asparagine residue. ${ }^{38}$ During hypoxia, asparagine hydroxylation is blocked and CBP/p300 recruitment is facilitated enabling increased levels of transcription. Factor-inhibiting HIF (FIH) hydroxylates the asparagine residue at position Asn803 in human HIF-1 $\alpha$, which corresponds to asparagine Asn851 in HIF-2 $\alpha .{ }^{39,40}$ Inhibition of FIH can result in increased HIF target gene expression even under severe hypoxia or in certain VHL-deficient cell lines. ${ }^{41}$

\section{Biological Functions not Involving HIF}

Aside from mediating HIF- $\alpha$ proteolysis, $\mathrm{pVHL}$ is involved in extracellular matrix (ECM) assembly matrix turnover, ${ }^{42-47}$ the regulation of intracellular junctions, ${ }^{48} \mathrm{NF}-\kappa \mathrm{B}$ signaling, ${ }^{49}$ the regulation of $\mathrm{c}$-Met receptor responsiveness to hepatocyte growth factor (HGF) involving $\beta$-catenin ${ }^{45,50}$ and the regulation of p53 transcriptional activity by suppressing Mdm2mediated ubiquitination and nuclear export. ${ }^{51}$ Furthermore, pVHL has been shown to regulate microtubule stability and cilia maintenance ${ }^{52-55}$ and controls the activity of plant homeodomain protein Jade-1, ${ }^{56,57}$ and atypical protein kinase $C$ isoforms. ${ }^{58-62}$ Other $\mathrm{pVHL}$ targets include a KRAB-A domain protein, VHLak, repressing HIF transcriptional activity, ${ }^{63}$ de-ubiquitinating enzymes, ${ }^{64}$ the large subunit of RNA polymerase $1 I^{65}$ and the RNA-binding protein hnRNP A2. ${ }^{66}$ How these HIF-independent pVHL functions and recently discovered protein interactions exactly contribute to the initiation and progression of VHL-associated tumorigenesis is unclear and requires further investigation.

\section{pVHL during Embryonic Development}

Genetic inactivation of pVHL in the mouse germ line results in death of the embryo during mid-gestation. Although placenta and embryo appear normal until embryonic day (E) E9.5, placentae from $V H L$-deficient embryos lack a properly developed syncytiotrophoblast and labyrinth and show evidence of hemorrhage by E11.5-12.5, suggesting that abnormal placental vascularization has led to the embryo's demise. ${ }^{67}$ This phenotype appears to be largely mediated by $\mathrm{HIF}$, since germ-line inactivation of HIF prolyl-hydroxylase domain (PHD) protein 2 resulted in similar, however, not identical pathology, ${ }^{68}$ indicating HIF-independent functions of either pVHL and/or PHD2 during placental development. $\mathrm{pVHL}$ is not only essential for normal placental development but also plays a critical role in the development, growth and differentiation of many other tissues. For example, tissuespecific inactivation of $\mathrm{pVHL}$ in neuro-epithelial progenitor cells resulted in abnormal neuronal differentiation and embryonic lethality during late gestation (VH Haase, unpublished data), and chondrocyte-specific inactivation of pVHL in the growth plate caused stunted bone growth, most likely a consequence of a HIF-dependent increase in cell cycle inhibitor $\mathrm{p} 57^{\mathrm{kip} 2}{ }^{69}$ In contrast, HIF-1 $\alpha$ inactivation in chondrocytes resulted in a lack of $\mathrm{p} 57^{\mathrm{kip} 2}$-mediated growth arrest, followed by massive apoptosis. ${ }^{70}$

\section{VHL Disease Manifestations in Mice with Germ-line Mutations}

Patients with VHL disease develop highly vascularized tumors in multiple organ systems, hemangioblastomas of the retina and CNS, CC-RCC and pheochromocytomas being the most prominent clinical manifestations. ${ }^{1} \mathrm{VHL}$ disease is grouped into two subtypes depending on the presence or absence of pheochromocytoma. Different clinical subtypes are associated with specific VHL mutations, which result in distinct functional and biochemical properties of the mutated $V H L$ gene product (for an overview see Neumann and Bender ${ }^{71}$, Clifford et al. ${ }^{72}$ and Hoffman et al. ${ }^{73}$ ). Clinical manifestations of VHL disease occur relatively early in life, usually between 10 and 40 years of age, whereas sporadic tumors with $\mathrm{VHL}$ mutations, such as CC-RCC present later in life. In addition to tumor formation, mutations in the $V H L$ gene can result in the development of polycythemia. ${ }^{74}$ Congenital Chuvash polycythemia is a rare endemic disease in central European Russia and is associated with a specific mutation of $\mathrm{VHL}$ codon 200 (C598T $\Rightarrow$ Arg200Trp). This mutation is transmitted in an autosomal-recessive manner, and affected individuals, who are homozygous for the mutation, are not predisposed to the development of typical VHL-associated tumors. ${ }^{75}$

In mice, germ-line loss of one $V H L$ allele $(V H L+/-)$ results in the development of cavernous liver hemangiomas, ${ }^{76}$ which is a rare manifestation of $\mathrm{VHL}$ disease in human. ${ }^{77,78}$ This phenotype is strongly dependent on the genetic background of heterozygous mice, as the incidence of liver hemangiomas in BALB/c mice was $88 \%$, but only $18 \%$ in a C57BL/6 
background, most likely reflecting polymorphic differences in modifier genes. $^{79}$

Although the molecular mechanism for this liver phenotype has not been systematically investigated, it is most likely that, following Knudson's two-hit hypothesis, inactivation of the remaining $V H L$ wild-type allele in hepatocytes resulted in the formation of cavernous hemangiomas through an increase in HIF-dependent vascular growth factor production. Hepatocyte-specific inactivation of $V H L$ using the Albumin-Cre and phosphoenolpyruvate carboxykinase (PEPCK)-Cre transgenes (Figure 1 and Table 1) phenocopies the liver pathology found in heterozygotes and suggests that liver hemangiomas in $V H L$ heterozygotes are the result of $\mathrm{pVHL}$ loss in hepatocytes and not in other liver cell types, such as endothelial cells. Endothelial cells, which express wild-type $V H L$ in this model, respond to uncontrolled and constitutive production of hepatocyte-derived vascular growth factors with proliferation. This is mechanistically similar to human VHLassociated hemangioblastomas, in which 'stromal cells' and not endothelial cells are $V H L$-deficient and represent the neoplastic component of these tumors. ${ }^{94}$ The histogenetic origin of stromal cells is uncertain; however, correlative evidence suggests that they may be derived from angiogenic progenitor cells. ${ }^{95,96}$

Another major visceral manifestation of VHL disease is the development of kidney cysts, which can occur in up to $60 \%$ of patients with $V H L$ germ-line mutations. ${ }^{1,97}$ Renal cysts, which occur more frequently than CC-RCC, are considered preneoplastic precursor lesions of CC-RCC. In $\mathrm{VHL}+/-$ mice renal cysts were only found at extremely low frequency $(<5 \%)$ by Haase et $a l .{ }^{76}$ and Kleymenova et al. ${ }^{98}$ In both reports, CC-RCCs were not observed, nor were CNS hemangioblastomas or retinal angiomas. Treatment with streptozotocin did not result in increased susceptibility to renal carcinogenesis, but increased the incidence of hemangiomas and hemangiosarcomas in the liver and other organs such as the uterus and ovaries. ${ }^{98}$

Although erythrocytosis is seen in a small fraction of patients with VHL disease, ${ }^{99,100}$ elevated hematocrits are not found in $V H L+/-$ mice. Mice homozygous for a $V H L$
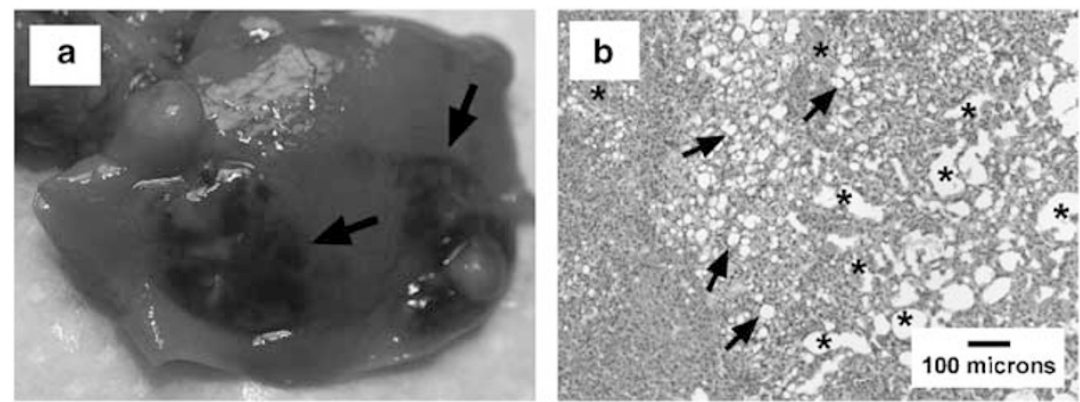

Figure 1 Hepatic vascular tumors in mice that lack pVHL in hepatocytes. (a) Gross photograph of a liver with multiple cavernous hemangiomas (arrows). (b) Histological features of cavernous liver hemangiomas. A paraffin-embedded tissue section stained with $\mathrm{H} \& \mathrm{E}$ is shown. Asterisks depict endothelial cell-lined, blood-filled cavities and areas of hemorrhage. VHL-associated liver hemangiomas are typically associated with macro- and microvesicular hepatocellular accumulation of neutral lipids, ${ }^{76}$ here depicted by arrows. Lipid accumulation is also a feature of stromal cells, the neoplastic component of VHL-associated central nervous system hemangioblastomas ${ }^{95,96}$

Table 1 Phenotypes generated by cell-type-specific inactivation of pVHL in mice

\begin{tabular}{|c|c|c|c|}
\hline References & $\begin{array}{l}\text { Cre transgenic } \\
\text { (promoter) }\end{array}$ & Cell type & Phenotype \\
\hline Ding et al. ${ }^{80}$ & NPHS2 (podocin) & Podocytes & $\begin{array}{l}\text { Kidney } \\
\text { Acute nephritis ( } 4 \text { weeks) with hematuria, proteinuria and renal insufficiency; } \\
\text { features characteristic of pauci-immune RPGN (crescentic glomerulonephritis } \\
\text { with prominent segmental fibrin deposition and fibrinoid necrosis, no immune } \\
\text { deposits); absence of circulating ANCA antibodies; both HIF- } 1 \alpha \text { and HIF-2 } \alpha \\
\text { protein levels were increased; upregulation of HIF-dependent genes (includin } \\
\text { CXCR4) as well as RPGN-associated genes; de novo expression of CXCR4 }\end{array}$ \\
\hline Brukamp et al. ${ }^{81}$ & NPHS2 (podocin) & Podocytes & $\begin{array}{l}\text { No prominent disease pattern in vivo; preserved glomerular development but } \\
\text { glomerulomegaly at a young age and occasional glomerulosclerosis; no } \\
\text { significant proteinuria; increased podocyte apoptosis in vitro }\end{array}$ \\
\hline Steenhard et al. ${ }^{82}$ & NPHS2 (podocin) & Podocytes & $\begin{array}{l}\text { Initially normal glomerular development; at } 16 \text { weeks ultrastructural changes, } \\
\text { such as foot process broadening, widespread irregular GBM thickening with } \\
\text { subepithelial hump formation and focal subendothelial delamination; proteinuri }\end{array}$ \\
\hline Rankin et al. ${ }^{83}$ & $\begin{array}{l}\text { PEPCK } \\
\text { (phosphoenolpyruvate } \\
\text { carboxykinase) }\end{array}$ & $\begin{array}{l}\text { Proximal renal } \\
\text { tubule }\end{array}$ & $\begin{array}{l}\text { Renal cysts at low frequency; inactivation of ARNT, but not HIF- } 1 \alpha \text { suppresse } \\
\text { the development of renal cysts }\end{array}$ \\
\hline $\begin{array}{l}\text { Haase et } \text { al. }^{76} \\
\text { Rankin et al. } \\
\text { Rankin et al. }\end{array}$ & Albumin & Hepatocytes & $\begin{array}{l}\text { Liver } \\
\text { Growth deficiency, angiectasis, hemangiomas, endothelial cell proliferation, } \\
\text { severe hepatic steatosis (neutral fat accumulation in hepatocytes), } \\
\text { inflammatory cell infiltration, erythrocytosis from increased liver EPO } \\
\text { production; HIF-2 is the main mediator of this phenotype; HIF-1 regulates } \\
\text { glycolytic gene expression }\end{array}$ \\
\hline
\end{tabular}


Table 1 (Continued)

\begin{tabular}{|c|c|c|c|}
\hline References & $\begin{array}{l}\text { Cre transgenic } \\
\text { (promoter) }\end{array}$ & Cell type & Phenotype \\
\hline $\begin{array}{l}\text { Peyssonnaux } \\
\text { et al. }\end{array}$ & Albumin & Hepatocytes & $\begin{array}{l}\text { Relative iron deficiency with hypochromia, poikilocytosis, microcytosis, } \\
\text { decreased total iron and ferritin levels; spleen also strongly iron deficient; } \\
\text { decreased hepcidin mRNA and protein levels (ARNT dependent); hepcidin } \\
\text { downregulation specifically due to the stabilization of HIF; significantly elevated } \\
\text { IL-6 and IL-1 levels; IL6- or IL1-mediated stimulation of hepcidin expression is } \\
\text { subordinate to the suppression by HIF; increased ferroportin expression in } \\
\text { brush border enterocytes of the duodenum, Kupffer cells and hepatocytes }\end{array}$ \\
\hline Rankin et al. ${ }^{31,32}$ & $\begin{array}{l}\text { PEPCK } \\
\text { (phosphoenolpyruvate } \\
\text { carboxykinase) }\end{array}$ & Hepatocytes & $\begin{array}{l}\text { Liver hemangiomas, polycythemia; HIF-2 } \alpha \text { is required for the development of } \\
\text { polycythemia and inactivation of HIF-2 } 2 \text { is sufficient to suppress hepatic EPO } \\
\text { expression in VHL-KO livers despite increased HIF-1 activity }\end{array}$ \\
\hline
\end{tabular}

Neumann et al. ${ }^{85} \quad$ Lck (lymphocyte protein Thymocytes tyrosine kinase)

\section{Immune system}

Diminished maximal $\mathrm{Ca}_{\mathrm{i}}^{2+}$ together with retarded initial rates of $\mathrm{Ca}_{\mathrm{i}}^{2+}$ elevation in response to CD3/CD4 co-ligation;

$\mathrm{Ca}^{2+}$ signaling was completely restored in $\mathrm{VHL}-/-/ H I F-1 \alpha-/-$ double $\mathrm{KO}$ thymocytes; stabilization of HIF- $1 \alpha$ increases flux of $\mathrm{Ca}^{2+}$ from the cytoplasm to the mitochondria and results in increased protein levels of SERCA2 $\left(\mathrm{Ca}^{2+}\right.$ pump that refills ER stores); overall SERCA-mediated $\mathrm{Ca}^{2+}$ transport is increased; both hypoxic and non-hypoxic-mediated HIF-1 $\alpha$ stabilization may minimize the strength and duration of $\mathrm{Ca}^{2+}$ signaling by means of acceleration of cytoplasmic $\mathrm{Ca}^{2+}$ clearance

Small, highly vascularized thymi; increased apoptosis in CD4/CD8 doublepositive cells involving a caspase8-dependent mechanism; phenotype is HIF-1 dependent. tyrosine kinase)

\begin{tabular}{|c|c|c|}
\hline Cramer et al. ${ }^{87}$ & LysM (lysozyme M) & Myeloid cells \\
\hline Karhausen et al. ${ }^{88}$ & $\begin{array}{l}\text { Fabp (fatty acid-binding } \\
\text { protein) }\end{array}$ & $\begin{array}{l}\text { Colonic } \\
\text { epithelial } \\
\text { cells }\end{array}$ \\
\hline Seagroves et al. ${ }^{89 a}$ & $\begin{array}{l}\text { WAP (whey acidic } \\
\text { protein) }\end{array}$ & $\begin{array}{l}\text { Mammary } \\
\text { gland } \\
\text { epithelium }\end{array}$ \\
\hline Boutin et al. ${ }^{90 a}$ & K14 (keratin 14) & Epidermis \\
\hline
\end{tabular}

Tang et al. ${ }^{91} \quad$ Tie2

Endothelial cells Increase in inflammatory response through HIF-1

\section{Epithelium}

Increased expression of HIF-regulated barrier protective factors such as intestinal trefoil factor; protection from inflammatory bowel disease clinically; accumulation of glycogen in luminal epithelial cells

Abnormal differentiation of gland epithelium during lactation in multiply bred mutants, collapsed alveoli, little or no milk production, enlarged blood vessels, no hyperplasia or tumors

Increased dermal vasculature, higher metabolic rate, low weight, early death, erythrocytosis

\section{Vascular system}

Intrauterine death with hemorrhages at E12.5; loss of HIF-1 $\alpha$ did not rescue the embryonic lethality; endocardial collapse, abnormal yolk sac vascular organization, reduced fibronectin deposition around vitelline vessels, defective extracellular fibronectin matrix assembly, defective vasculogenesis in the placental labyrinth, dilated vessels and reduced vessel complexity; increased permeability of the endothelial monolayer; impaired migration and impaired adhesion partially rescued with external fibronectin; regulation of fibronectin assembly independent of HIF-1

\section{Connective tissue}

Wang et al..$^{92} \quad$ OC (osteocalcin) Osteoblasts

Bone modeling is increased within the first week of life but appears to decline at latter stages of development; extremely dense, heavily vascularized long bones; progressively increased vessel numbers with age; trabecular separation reduced; no detectable changes in calvarial bone morphology; upregulation of HIF-1 and HIF-2 and VEGF, serum level of VEGF was not elevated; conversely, inactivation of HIF-1 $\alpha$ in the osteoblast produced the reverse phenotype, that is, thinner and less vascularized bones

Pfander et al. ${ }^{69} \quad$ Colll (collagen II)

Growth plate/ chondrocytes

Hong et al. ${ }^{93}$

ROSA26-tamoxifen-

Mosaic

Severe dwarfism, severe decrease in chondrocyte proliferation, upregulation of HIF-1-dependent p57 ${ }^{\text {kip2 }}$, increased extracellular matrix deposition

\section{Mosaic and neurons}

Distinct changes at E14.5; embryonic lethality; small, pale embryos; extensive hemorrhage; vascular defects and liver damage in the embryos, but no major placental defects prior to death; no significant increase in apoptosis or decrease in proliferation

Hepatic vascular tumors; angiectasis in heart, liver, pancreas, lung, kidney; infertility, abnormal spermatogenesis

Mosaic

Abnormal neuronal differentiation, embryonic lethality

Haase et al. $\beta$-actin-tamoxifeninducible ER-Cre Nestin 
mutation at codon 200, which does not result in embryonic lethality when bred to homozygosity, developed mild HIF-2dependent erythrocytosis, thus mimicking features of human Chuvash polycythemia. ${ }^{101}$

\section{pVHL and Renal Cell Cancer}

A molecular hallmark of the most common form of kidney cancer, CC-RCC, is mutated pVHL. In contrast to patients with VHL disease, who transmit germ-line mutations, patients with sporadic CC-RCC have acquired somatic mutations in both copies of the VHL gene. VHL-associated CC-RCCs are often preceded by multifocal and bilateral renal cysts, which can be found in up to $60 \%$ of patients with VHL disease and can sometimes mimic polycystic kidney disease. ${ }^{1,97} \mathrm{VHL}-$ associated renal cysts can be malignant or benign, and should be viewed as preneoplastic lesions. Renal cystogenesis in general is associated with altered signaling through the primary cilium, a microtubule-based organelle, which is found in many cell types such as neurons, photoreceptors, fibroblasts and others, and predominantly functions as a luminal flow sensor on renal epithelial cells and regulates renal tubular cell proliferation. ${ }^{102}$ More recent studies have proposed that $\mathrm{pVHL}$ is essential for cilium maintenance. ${ }^{52-55,103}$ pVHL was reported to cooperate with GSK3 $\beta$ in an interlinked signaling pathway that maintains the primary cilium. ${ }^{53}$ Schermer et al. ${ }^{54}$ demonstrated that $\mathrm{pVHL}$ localizes to the monocilia of kidney cells, interacts with Par3-Par6-aPKC and controls ciliogenesis via coordinated extension of microtubules toward the cell periphery and Esteban et al. ${ }^{103}$ proposed a role for HIF in cilium maintenance. The latter study showed that $\mathrm{pVHL}$ inactivation is associated with the loss of the primary cilium in VHL-defective cell lines and in kidney cysts found in patients with VHL disease, and that reconstitution of cell lines with wild-type pVHL restored primary cilia in a HIFdependent manner. Although CC-RCCs are traditionally believed to arise from the proximal renal tubule, ${ }^{97,104}$ their histogenetic origin remains controversial. Recent immunohistochemical studies suggested that CC-RCC originates from distal nephron segments, which express Tamm-Horsfall protein (THP). ${ }^{105}$ While certain features of $V H L$-deficient tumors, for example, their highly vascular nature resulting from increased VEGF production, can be directly linked to constitutive HIF stabilization, renal carcinogenesis is more difficult to understand and cannot be explained by activated HIF signaling alone. However, loss of pVHL function and subsequent HIF- $\alpha$ stabilization represent the earliest detectable molecular events in renal tumorigenesis. ${ }^{105}$ Esteban et al. ${ }^{106}$ showed that $\mathrm{pVHL}$ inactivation is associated with downregulation of intercellular adhesion molecule E-cadherin in pre-cancerous lesions and that both HIF-1 and HIF-2 contributed to decreased E-cadherin expression with HIF-2 mediating a more potent suppression in CC-RCC cell lines. Similarly, Evans et al. ${ }^{107}$ demonstrated that knockdown of pVHL resulted in E-cadherin suppression via HIF-dependent induction of E2 box-dependent transcriptional repressors Snail and SIP1, and Krishnamachary et al. ${ }^{108}$ reported that HIF-1 activation in VHL-deficient cells downregulated Ecadherin, led to the loss of cell-cell adhesion and promoted epithelial to mesenchymal transition through the induction of transcriptional repressors TCF3, ZFHX1A and ZFHX1B/SIP1. Therefore, cellular changes, such as loss of intercellular junctions and epithelial de-differentiation involving HIFdependent as well as HIF-independent molecular pathways ${ }^{48,106-108}$ in addition to HIF-dependent and -independent alterations in p53 or NF- $\kappa$ B activity, ${ }^{34,35,49,51}$ HGF signaling, ${ }^{45,50,109}$ and modifications in ECM turnover and re-modeling ${ }^{42-47}$ create the molecular environment for the development CC-RCC, which most likely requires additional genetic events. The importance of HIF activation in CC-RCC pathogenesis and growth is furthermore underscored by experimental and clinical studies, which demonstrated that inhibition of HIF- $\alpha$ translation by pharmacological targeting of mTOR correlated with reduced tumor growth, ${ }^{110}$ and that increased expression of certain HIF target genes, such as CXCR4, as well as E-cadherin suppression was associated with disease progression. ${ }^{111,112}$ With regard to the contribution of individual HIF- $\alpha$ homologs to renal tumor development, it is of interest that a substantial number of $V H L$-defective CCRCC cell lines do not express HIF- $1 \alpha$, but express HIF- $2 \alpha{ }^{7}$ Furthermore a bias toward HIF-2 $\alpha$ expression was also found in clinical CC-RCC samples with confirmed $V H L$ defect. $^{113}$ This is in contrast to normal, non-transformed renal epithelial cells, in which HIF-2 $\alpha$ is usually not detectable during hypoxia/ ischemia. ${ }^{114}$ Thus, VHL-associated tumor development may depend on a shift in the ratio of HIF- $1 \alpha$ versus HIF- $2 \alpha$ levels toward an increase in HIF-2 $\alpha$. In support of this hypothesis are studies in CC-RCC cell lines, which suggest that HIF-2 in contrast to HIF-1 is oncogenic and is able to override pVHL's tumor suppressor function. ${ }^{115-118}$ HIF-2 has been proposed to preferentially regulate molecular pathways critical for renal cell growth, such as signaling through the TGF- $\alpha$ /epidermal growth factor receptor pathway, cyclin D1 and the c-Myc proto-oncogene. ${ }^{119-124}$ Taken together, there is substantial evidence that HIF-1 and HIF-2 have diverse functions with regard to $\mathrm{VHL}$ renal tumorigenesis, which could be exploited therapeutically, and may be strongly context dependent. ${ }^{125}$ Not much is known about the role of HIF-3 $\alpha$ in VHL-associated tumorigenesis. Recent studies, however, have suggested that a specific splice form of HIF- $3 \alpha$, HIF- $3 \alpha 4$, inhibits renal tumor growth through abrogation of HIF-2 signaling. ${ }^{126}$

To overcome embryonic lethality and to generate a mouse model of VHL-associated CC-RCC, we have used Cre/loxPmediated gene targeting to inactivate $\mathrm{pVHL}$ in adult renal tissues. In the conditional VHL allele, promoter and exon 1 are flanked by loxP sites and are deleted upon Cre-mediated recombination, resulting in a mutated $V H L$ allele that is transcriptionally inactive. ${ }^{76}$ Similar to our approach, Ma et al. ${ }^{79}$ generated a conditional $V H L$ allele in which exons 2 and 3 were floxed. To specifically target renal epithelial cell types from which CC-RCCs are thought to originate, we generated transgenic mice, which express Cre in proximal and distal renal tubule segments under control of either a mutated version of the rat PEPCK or the THP promoter ${ }^{83}$ (also EB Rankin et al., unpublished observations). PEPCK-Cre mutant mice developed renal cysts at a frequency of $\sim 20 \%$, but CC-RCC was not observed (Figure 2). Renal cyst development in PEPCK-Cre mutant was dependent on intact HIF signaling, but not on HIF-1 $\alpha$, as cysts were not observed in $V H L / A R N T$ double knockout mice and HIF-1 $\alpha$ was not 

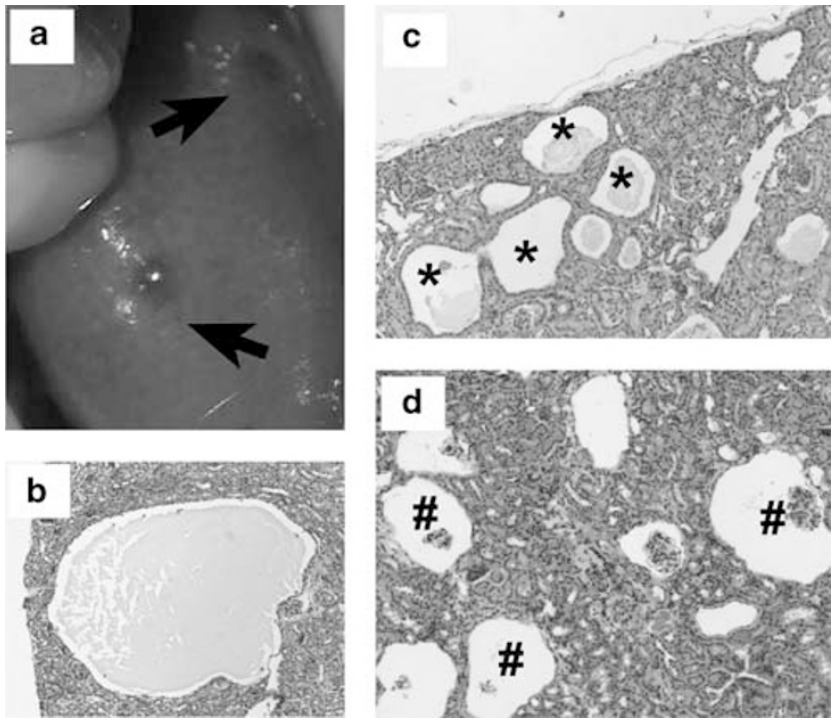

Figure 2 Mice that lack pVHL in the proximal renal tubule develop tubular and glomerular cysts. (a) Gross in situ photograph of a kidney from a male PEPCK-Cre mutant with two macroscopically visible cysts (arrows). The PEPCK-Cre transgene was used to inactivate $\mathrm{PVHL}$ in the proximal renal tubule. Genetic analysis with compound knockout mice demonstrated that this phenotype was HIF dependent. ${ }^{83}$ (b-d) Histological features of cystic changes found in $\mathrm{H} \& \mathrm{E}$-stained paraffin sections from VHL-deficient kidneys. A large cortical cyst (b), a cluster of renal tubular cysts lined by cuboidal epithelium (asterisks in $\mathbf{c}$ ) and an area of glomerular cysts (number sign in d) are shown. CC-RCC or dysplastic changes in cysts were not found in VHL-deficient kidneys. Magnification is $\times 100$

required for cyst formation. ${ }^{83}$ Activation of HIF signaling has also been suggested to promote renal cystogenesis in a mouse model of fumarate hydratase deficiency, which leads to HIF prolyl-hydroxylase inhibition and HIF- $\alpha$ stabilization, ${ }^{127}$ indicating that HIF-mediated renal cystogenesis is not dependent on $V H L$ status. In contrast to $\mathrm{pVHL}$ inactivation with PEPCK-Cre transgenics, inactivation of $\mathrm{pVHL}$ using THP-Cre, which targets the medullary thick ascending loop of Henle (mTAL) and the early distal tubule, did not produce renal cysts. CC-RCCs were not observed in THP-Cre mutant animals. Renal tumors were also not found by $\mathrm{Ma}$ et al. $^{79}$ when an inducible $\beta$-actin promoter-driven Cre was used to generate mice which lacked pVHL in a mosaic pattern. The absence of renal tumorigenesis in $V H L$-deficient mice in conjunction with genetic data from humans suggests that transformation of renal cysts into CC-RCC most likely requires additional genetic events such as mutations in other tumor suppressor genes or oncogenes (Figure 3 ).

\section{VHL Phenotypes in Non-Renal Tissues: is it All HIF?}

To study the role of $\mathrm{pVHL}$ in growth, differentiation and normal tissue physiology, we have used different Cre transgenic lines to inactivate $\mathrm{pVHL}$ in multiple tissues. Table 1 summarizes clinical phenotypes that we and others have observed. Inactivation of $\mathrm{pVHL}$ results in abnormal cellular differentiation and growth causing significant organ pathology in many tissues, one common feature being increased vascularity. Although HIF-mediated stimulation of vascular growth factor

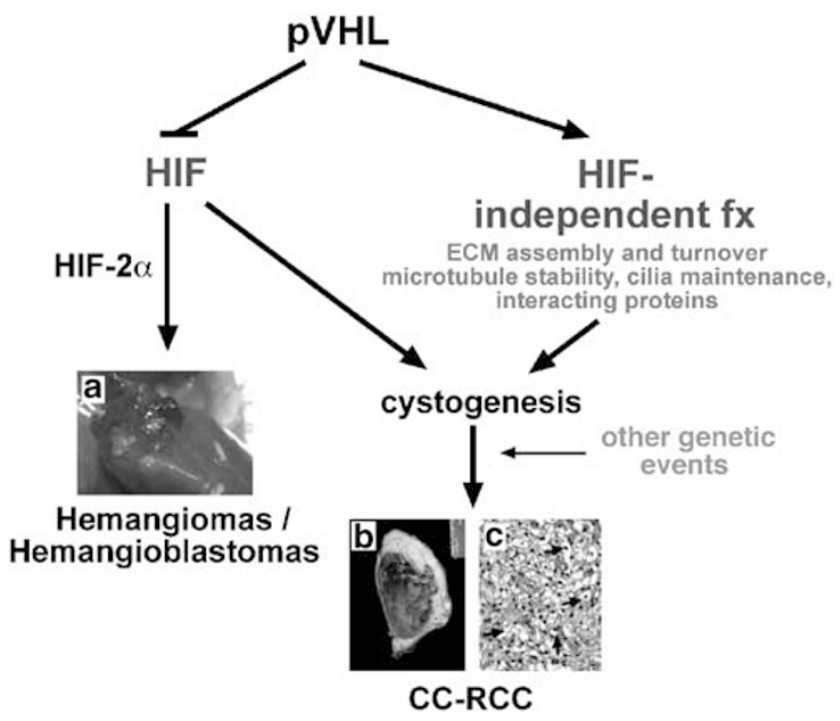

Figure 3 Schematic illustrating the role of $\mathrm{pVHL}$ and $\mathrm{HIF}$ in the development of the VHL phenotype. While activation of HIF signaling is required and sufficient for vascular tumor development, renal cystogenesis in humans may be a result of HIF activation \pm loss of HIF-independent functions of pVHL. CC-RCC development most likely requires additional mutations in other tumor suppressor genes or in certain oncogenes. (a) Gross photography of a liver hemangioma found in a VHL mutant mouse. (b, c) Human renal cell carcinoma of the clear cell type (CC-RCC); (b) gross photography; (c) PAS stain of CC-RCC, clear cells are depicted by arrows, magnification $\times 400$; images $(b, c)$ were kindly provided by Dr. John Tomaszewski, Department of Pathology, University of Pennsylvania School of Medicine, Philadelphia, PA, USA

production can explain increased vascularity, the effects of pVHL gene deletion on cellular growth and differentiation, metabolism and organ function are not as easily understood. In a non-RCC tumor model, Mack et al. ${ }^{128}$ found significant growth retardation in teratocarcinomas derived from $\mathrm{VHL}-1-$ embryonic stem cells. These findings were surprising, but are in concordance with observations made by Carmeliet et al. ${ }^{129}$ who showed that HIF- $\alpha$-deficient teratocarcinomas had a growth advantage compared to wild type. However, growth suppression in $V H L-/$ - teratocarcinomas may not be entirely dependent on HIF-1, as introduction of a mutated pVHL species $(\mathrm{Y} 112 \mathrm{H})$ into the $\mathrm{VHL}-/-$ background remained growth suppressive despite restoration of HIF- $\alpha$ regulation, ${ }^{130}$ suggesting HIF-independent functions of $\mathrm{pVHL}$ in this model.

To determine the role of individual HIF transcription factors in the development of the VHL phenotype in mice, we generated tissue-specific pVHL knockout mice, which lack HIF- $1 \alpha$ and/or HIF-2 $\alpha$ or HIF-1 $\beta$ (ARNT). Using this compound knockout approach, Biju et al. ${ }^{86}$ was able to show that a caspase-8-dependent pro-apoptotic phenotype in $\mathrm{VHL}-/$ thymocytes was completely HIF-1 mediated. HIF-2 $\alpha$, on the other hand, although expressed in thymocytes, was found to be non-functional and inactivation of HIF- $1 \alpha$ alone was sufficient to completely suppress VEGF mRNA levels and the vascular phenotype in $V H L-/-$ thymi. ${ }^{86}$ This is contrast to the VHL-deficient liver, where inactivation of HIF- $1 \alpha$, expressed and functional in hepatocytes, did not affect VHL-associated vascular tumorigenesis, while inactivation of HIF-2 $\alpha$ was sufficient to prevent the development of 
Table 2 Mouse phenotypes resulting from HIF activation in tissues with wild-type $V H L$

\begin{tabular}{|c|c|c|c|}
\hline References & $\begin{array}{l}\text { Cre transgenic } \\
\text { (promoter) }\end{array}$ & Cell type & Phenotype \\
\hline \multicolumn{4}{|l|}{ (a) } \\
\hline \multirow[t]{3}{*}{ Kim et al. ${ }^{133}$} & $\begin{array}{l}\text { Albumin; HIF1dPA } \\
\text { (non-degradable } \\
\text { HIF-1 } \alpha \text { ) }\end{array}$ & Hepatocytes & $\begin{array}{l}\text { Liver } \\
\text { Normal lifespan, normal appearing liver but with fine vacuolization } \\
\text { of hepatocytes; moderate lipid accumulation (microvesicular } \\
\text { pattern); normal proliferation }\end{array}$ \\
\hline & $\begin{array}{l}\text { Albumin; HIF2dPA } \\
\text { (non-degradable } \\
\text { HIF-2 } \alpha \text { ) }\end{array}$ & Hepatocytes & $\begin{array}{l}\text { Death at } 6-8 \text { weeks, marked hepatomegaly, polycythemia from } \\
\text { increased liver EPO production; angiectasis; minimal } \\
\text { vacuolization of hepatocytes; increased proliferation }\end{array}$ \\
\hline & $\begin{array}{l}\text { Albumin; HIF1dPA/ } \\
\text { HIF2dA }\end{array}$ & Hepatocytes & $\begin{array}{l}\text { Death at } 6-8 \text { weeks; marked hepatomegaly; angiectasis; micro- } \\
\text { and macrovesicular hepatic steatosis (histologically identical to } \\
\text { Albumin-Cre } V H L-/- \text { mutants), increased proliferation; } \\
\text { polycythemia }\end{array}$ \\
\hline \multirow{3}{*}{ Kim et al. ${ }^{133}$} & & & Skin \\
\hline & $\begin{array}{l}\text { K14 (keratin 14); } \\
\text { HIF1dPA }\end{array}$ & Basal keratinocytes & No gross skin phenotype \\
\hline & $\begin{array}{l}\text { K14 (keratin 14); } \\
\text { HIF2dPA }\end{array}$ & Basal keratinocytes & $\begin{array}{l}\text { Formation of non-leaky blood vessels; partial alopecia; runting; } \\
\text { epidermal proliferation; weight loss }\end{array}$ \\
\hline \multicolumn{4}{|l|}{ (b) } \\
\hline \multirow{3}{*}{ Takeda et al. ${ }^{68}$} & & & Early embryo and mosaic \\
\hline & $\begin{array}{l}\text { Ella (adenovirus } \\
\text { promoter) }\end{array}$ & $\begin{array}{l}\text { General deleter, } \\
\text { early embryo prior to } \\
\text { implantation }\end{array}$ & $\begin{array}{l}\text { PHD2-/-: } \\
\text { Embryonic lethality occurred between E12.5-E14.5; placental } \\
\text { defects included significantly reduced labyrinthine branching } \\
\text { morphogenesis, widespread penetration of the labyrinth by } \\
\text { spongiotrophoblasts and abnormal distribution of trophoblast giant } \\
\text { cells; in heart underdevelopment of the trabeculae, remarkably } \\
\text { thinner myocardium, and incomplete formation of the } \\
\text { interventricular septum; increased HIF- } \alpha \text { in the placenta and the } \\
\text { embryo proper but not in the heart; VEGF unchanged in heart and } \\
\text { placentae; increased expression of MASH2 and decreased } \\
\text { expression of TFEB and GCM1 }\end{array}$ \\
\hline & $\begin{array}{l}\text { Ella (adenovirus } \\
\text { promoter) }\end{array}$ & $\begin{array}{l}\text { General deleter, } \\
\text { early embryo }\end{array}$ & $\begin{array}{l}\text { PHD1-/- and PHD3-/-: } \\
\text { Viable; normal placenta and cardiovascular development; HIF- } \alpha \\
\text { and VEGF protein levels unchanged }\end{array}$ \\
\hline \multirow[t]{2}{*}{ Takeda et al. ${ }^{134}$} & $\begin{array}{l}\text { ROSA26-tamoxifen- } \\
\text { inducible ER-Cre }\end{array}$ & Mosaic & $\begin{array}{l}\text { PHD2-l-: } \\
\text { At } 6 \text { weeks, after tamoxifen treatment, ear, trachea, liver, lung, } \\
\text { renal cortex and brain with increased angiogenesis and } \\
\text { angiectasia; glomerulomegaly with capillary dilatations; severe } \\
\text { polycythemia; serum VEGF levels increased but no localized } \\
\text { VEGF mRNA upregulation }\end{array}$ \\
\hline & $\begin{array}{l}\text { ROSA26-tamoxifen- } \\
\text { inducible ER-Cre }\end{array}$ & Mosaic & $\begin{array}{l}\text { PHD1-/- and PHD3-/-: } \\
\text { No significant vascular phenotype; serum VEGF levels not } \\
\text { increased }\end{array}$ \\
\hline
\end{tabular}

A summary of mouse phenotypes resulting from the conditional activation of non-degradable forms of HIF-1 $\alpha$ (HIF1dPA) and/or HIF-2 $\alpha$ (HIF2dPA) using Cre-loxPmediated recombination (a), and from conditional inactivation of PHD1, 2 and 3 (b) is presented

cavernous hemangiomas (EB Rankin and VH Haase, submitted). This finding is consistent with the observation that angiogenic gene expression in hepatocytes, similar to the regulation of EPO, is strongly HIF-2 dependent ${ }^{32}$ (also EB Rankin and $\mathrm{VH}$ Haase, submitted) and illustrates, that although HIF-1 and HIF-2 have the capability to regulate the same target genes, preferential transcriptional activation by HIF-1 or HIF-2 in the setting of VHL deficiency and/or hypoxia is tissue- or context-dependent. ${ }^{120}$ Whether this requires tissue-specific transcriptional co-activators or repressors, certain DNA or protein modifications or other signaling events warrants further investigation. ${ }^{131}$ Whatever the underlying mechanisms, clinical studies have also demonstrated a correlation between HIF- $2 \alpha$ expression and the development of VHL-associated angiogenic lesions, ${ }^{132}$ suggesting that pharmacological targeting of HIF-2 may by an effective therapy for the treatment of these tumors.
pVHL- and pVHL/ARNT-deficient liver tissues are histologically similar and direct comparison of gene expression changes has not revealed major differences ${ }^{31}$ (also VH Haase et al., unpublished observation), suggesting that the effects of $\mathrm{pVHL}$ gene deletion in the liver are largely HIF mediated. Indeed, forced expression of non-degradable HIF- $1 \alpha$ and HIF- $2 \alpha$ phenocopied the $\mathrm{VHL}$ phenotype in the liver and $\mathrm{skin}^{133}$ (Table 2a). Similarly, genetic inactivation of PHD2 in the mouse germ line resulted in placental changes that resembled, but were not identical to those observed in $V H L$ knockout mice. ${ }^{68}$ PHD2, one of three major mammalian HIF prolyl-hydroxylases, is essential for HIF- $\alpha$ degradation under normoxia, ${ }^{68,134,135}$ while PHD3 seems to be important for hydroxylation of HIF- $\alpha$ during re-oxygenation. ${ }^{136}$ Analysis of tissue-specific $P H D$ knockout mice and direct comparison with VHL phenotypes is therefore likely to provide novel insights into HIF-dependent and -independent functions of pVHL (see Table 2b). 


\section{Concluding Remarks}

The pVHL E3-ubiquitin ligase complex is essential for HIF- $\alpha$ proteolysis under normoxia and thus plays a critical role during embryonic development and for normal tissue physiology in the adult. In this review, we have summarized findings from the analysis of tissue-specific VHL knockout mice and have discussed the role of individual HIF transcription factors in the development of $\mathrm{VHL}$ phenotypes and in the context of VHL-associated tumorigenesis. While $\mathrm{pVHL}$ has biological functions that do not involve the HIF pathway, most organ pathologies in VHL knockout mice result from constitutive activation of HIF signaling with context- and tissue-specific contributions of HIF-1 and HIF-2 transcription factors. For a more comprehensive understanding of $\mathrm{pVHL}$ 's HIF-independent functions in tumor suppression, development and normal tissue physiology, additional genetic studies are needed that investigate and directly compare HIF signaling in wild-type and $V H L$-deficient backgrounds.

Acknowledgements. $\mathrm{VHH}$ is supported by grants from the National Cancer Institute $(\mathrm{NCl})$, the National Institute of Diabetes and Digestive and Kidney Diseases (NIDDK) and the American Heart Association (AHA). Because of space limitations, the authors were unable to accommodate all relevant references and apologize to our colleagues whose work was not cited.

1. Lonser RR, Glenn GM, Walther M, Chew EY, Libutti SK, Linehan WM et al. von HippelLindau disease. Lancet 2003; 361: 2059-2067.

2. Gnarra JR, Tory K, Weng Y, Schmidt L, Wei MH, Li H et al. Mutations of the VHL tumour suppressor gene in renal carcinoma. Nat Genet 1994; 7: 85-90.

3. Latif F, Tory K, Gnarra J, Yao M, Duh FM, Orcutt ML et al. Identification of the von HippelLindau disease tumor suppressor gene [see comments]. Science 1993; 260: 1317-1320.

4. lliopoulos O, Levy AP, Jiang C, Kaelin Jr WG, Goldberg MA. Negative regulation of hypoxia-inducible genes by the von Hippel-Lindau protein. Proc Natl Acad Sci USA 1996; 93: 10595-10599.

5. Gnarra JR, Zhou S, Merrill MJ, Wagner JR, Krumm A, Papavassiliou E et al. Posttranscriptional regulation of vascular endothelial growth factor mRNA by the product of the VHL tumor suppressor gene. Proc Natl Acad Sci USA 1996; 93: 10589-10594.

6. Siemeister G, Weindel K, Mohrs K, Barleon B, Martiny-Baron G, Marme D. Reversion of deregulated expression of vascular endothelial growth factor in human renal carcinoma cells by von Hippel-Lindau tumor suppressor protein. Cancer Res 1996; 56: 2299-2301.

7. Maxwell PH, Wiesener MS, Chang GW, Clifford SC, Vaux EC, Cockman ME et al. The tumour suppressor protein VHL targets hypoxia-inducible factors for oxygen-dependent proteolysis [see comments]. Nature 1999; 399: 271-275.

8. Kibel A, lliopoulos O, DeCaprio JA, Kaelin Jr WG. Binding of the von Hippel-Lindau tumor suppressor protein to Elongin B and C [see comments]. Science 1995; 269: 1444-1446.

9. Pause A, Lee S, Worrell RA, Chen DY, Burgess WH, Linehan WM et al. The von HippelLindau tumor-suppressor gene product forms a stable complex with human CUL-2, a member of the Cdc53 family of proteins. Proc Natl Acad Sci USA 1997; 94: 2156-2161.

10. Kamura T, Koepp DM, Conrad MN, Skowyra D, Moreland RJ, lliopoulos 0 et al. Rbx1, a component of the VHL tumor suppressor complex and SCF ubiquitin ligase [see comments]. Science 1999; 284: 657-661.

11. Stebbins CE, Kaelin Jr WG, Pavletich NP. Structure of the VHL-ElonginC-ElonginB complex: implications for VHL tumor suppressor function. Science 1999; 284: 455-461.

12. Feldman DE, Thulasiraman V, Ferreyra RG, Frydman J. Formation of the VHL-elongin BC tumor suppressor complex is mediated by the chaperonin TRiC. Mol Cell 1999; 4 1051-1061.

13. Iwai K, Yamanaka K, Kamura T, Minato N, Conaway RC, Conaway JW et al. Identification of the von Hippel-lindau tumor-suppressor protein as part of an active E3 ubiquitin ligase complex. Proc Natl Acad Sci USA 1999; 96: 12436-12441.

14. Lisztwan J, Imbert G, Wirbelauer C, Gstaiger M, Krek W. The von Hippel-Lindau tumor suppressor protein is a component of an E3 ubiquitin-protein ligase activity. Genes Dev 1999; 13: 1822-1833

15. Salceda S, Caro J. Hypoxia-inducible factor 1alpha (HIF-1alpha) protein is rapidly degraded by the ubiquitin-proteasome system under normoxic conditions. Its stabilization by hypoxia depends on redox-induced changes. J Biol Chem 1997; 272: 22642-22647.

16. Cockman ME, Masson N, Mole DR, Jaakkola P, Chang GW, Clifford SC et al. Hypoxia inducible factor-alpha binding and ubiquitylation by the von Hippel-Lindau tumor suppressor protein. J Biol Chem 2000; 275: 25733-25741.
17. Tanimoto K, Makino Y, Pereira T, Poellinger L. Mechanism of regulation of the hypoxiainducible factor-1 alpha by the von Hippel-Lindau tumor suppressor protein. EMBO J 2000; 19: 4298-4309.

18. Ohh M, Park CW, Ivan M, Hoffman MA, Kim TY, Huang LE et al. Ubiquitination of hypoxia-inducible factor requires direct binding to the beta-domain of the von HippelLindau protein. Nat Cell Biol 2000; 2: 423-427.

19. Kamura T, Sato S, Iwai K, Czyzyk-Krzeska M, Conaway RC, Conaway JW. Activation of HIF1alpha ubiquitination by a reconstituted von Hippel-Lindau (VHL) tumor suppressor complex. Proc Natl Acad Sci USA 2000; 97: 10430-10435.

20. Maynard MA, Qi H, Chung J, Lee EH, Kondo Y, Hara S et al. Multiple splice variants of the human HIF-3alpha locus are targets of the VHL E3 ubiquitin ligase complex. J Biol Chem 2003; 278: 1032-1040.

21. Jaakkola P, Mole DR, Tian YM, Wilson MI, Gielbert J, Gaskell SJ et al. Targeting of HIFalpha to the von Hippel-Lindau ubiquitylation complex by $\mathrm{O}_{2}$-regulated prolyl hydroxylation. Science 2001; 292: 468-472.

22. Ivan M, Kondo $\mathrm{K}$, Yang H, Kim W, Valiando J, Ohh M et al. HIFalpha targeted for VHLmediated destruction by proline hydroxylation: implications for $\mathrm{O}_{2}$ sensing. Science 2001; 292: 464-468.

23. Epstein AC, Gleadle JM, McNeill LA, Hewitson KS, O'Rourke J, Mole DR et al. C.elegans EGL-9 and mammalian homologs define a family of dioxygenases that regulate HIF by prolyl hydroxylation. Cell 2001; 107: 43-54.

24. Hon WC, Wilson MI, Harlos K, Claridge TD, Schofield CJ, Pugh CW et al. Structural basis for the recognition of hydroxyproline in HIF-1 alpha by pVHL. Nature 2002; 417: 975-978.

25. Masson N, Willam C, Maxwell PH, Pugh CW, Ratcliffe PJ. Independent function of two destruction domains in hypoxia-inducible factor-alpha chains activated by prolyl hydroxylation. EMBO J 2001; 20: 5197-5206.

26. Yu F, White SB, Zhao Q, Lee FS. HIF-1alpha binding to VHL is regulated by stimulussensitive proline hydroxylation. Proc Natl Acad Sci USA 2001; 98: 9630-9635.

27. Bruick RK, McKnight SL. A conserved family of prolyl-4-hydroxylases that modify HIF. Science 2001; 294: 1337-1340.

28. Wenger RH, Stiehl DP, Camenisch G. Integration of oxygen signaling at the consensus HRE. SCi STKE 2005; 2005: re12.

29. Hu CJ, Wang LY, Chodosh LA, Keith B, Simon MC. Differential roles of hypoxia-inducible factor 1alpha (HIF-1alpha) and HIF-2alpha in hypoxic gene regulation. Mol Cell Biol 2003; 23: 9361-9374.

30. Warnecke C, Zaborowska Z, Kurreck J, Erdmann VA, Frei U, Wiesener M et al. Differentiating the functional role of hypoxia-inducible factor (HIF)-1alpha and HIF-2alpha (EPAS-1) by the use of RNA interference: erythropoietin is a HIF-2alpha target gene in Hep3B and Kelly cells. FASEB J 2004; 18: 1462-1464.

31. Rankin EB, Higgins DF, Walisser JA, Johnson RS, Bradfield CA, Haase VH. Inactivation of the arylhydrocarbon receptor nuclear translocator (Arnt) suppresses von HippelLindau disease-associated vascular tumors in mice. Mol Cell Biol 2005; 25: 3163-3172.

32. Rankin EB, Biju MP, Liu Q, Unger TL, Rha J, Johnson RS et al. Hypoxia-inducible factor-2 (HIF-2) regulates hepatic erythropoietin in vivo. J Clin Invest 2007; 117: 1068-1077.

33. Gruber M, Hu CJ, Johnson RS, Brown EJ, Keith B, Simon MC. Acute postnatal ablation of Hif-2alpha results in anemia. Proc Natl Acad Sci USA 2007; 104: 2301-2306.

34. An WG, Kanekal M, Simon MC, Maltepe E, Blagosklonny MV, Neckers LM. Stabilization of wild-type p53 by hypoxia-inducible factor 1alpha. Nature 1998; 392: 405-408.

35. Ravi R, Mookerjee B, Bhujwalla ZM, Sutter CH, Artemov D, Zeng $\mathrm{Q}$ et al. Regulation of tumor angiogenesis by p53-induced degradation of hypoxia-inducible factor 1alpha. Genes Dev 2000; 14: 34-44.

36. Koshiji M, Kageyama Y, Pete EA, Horikawa I, Barrett JC, Huang LE. HIF-1alpha induces cell cycle arrest by functionally counteracting Myc. EMBO J 2004; 23: 1949-1956.

37. Gustafsson MV, Zheng X, Pereira T, Gradin K, Jin S, Lundkvist J et al. Hypoxia requires notch signaling to maintain the undifferentiated cell state. Dev Cell 2005; 9: 617-628.

38. Lando D, Peet DJ, Whelan DA, Gorman JJ, Whitelaw ML. Asparagine hydroxylation of the HIF transactivation domain a hypoxic switch. Science 2002; 295: 858-861.

39. Mahon PC, Hirota K, Semenza GL. FIH-1: a novel protein that interacts with HIF-1alpha and VHL to mediate repression of HIF-1 transcriptional activity. Genes Dev 2001; 15 : 2675-2686.

40. Lando D, Peet DJ, Gorman JJ, Whelan DA, Whitelaw ML, Bruick RK. FIH-1 is an asparaginyl hydroxylase enzyme that regulates the transcriptional activity of hypoxiainducible factor. Genes Dev 2002; 16: 1466-1471.

41. Stolze IP, Tian YM, Appelhoff RJ, Turley H, Wykoff CC, Gleadle JM et al. Genetic analysis of the role of the asparaginyl hydroxylase factor inhibiting hypoxia-inducible factor (HIF) in regulating HIF transcriptional target genes. J Biol Chem 2004; 279: 42719-42725.

42. Kurban G, Duplan E, Ramlal N, Hudon V, Sado Y, Ninomiya Y et al. Collagen matrix assembly is driven by the interaction of von Hippel-Lindau tumor suppressor protein with hydroxylated collagen IV alpha 2. Oncogene 200713 August [Epub ahead of print].

43. Kurban G, Hudon V, Duplan E, Ohh M, Pause A. Characterization of a von Hippel Lindau pathway involved in extracellular matrix remodeling, cell invasion, and angiogenesis. Cancer Res 2006; 66: 1313-1319.

44. Ohh M, Yauch RL, Lonergan KM, Whaley JM, Stemmer-Rachamimov AO, Louis DN et al. The von Hippel-Lindau tumor suppressor protein is required for proper assembly of an extracellular fibronectin matrix. Mol Cell 1998; 1: 959-968.

45. Koochekpour S, Jeffers M, Wang PH, Gong C, Taylor GA, Roessler LM et al. The von Hippel-Lindau tumor suppressor gene inhibits hepatocyte growth factor/scatter 
factor-induced invasion and branching morphogenesis in renal carcinoma cells. Mol Cell Biol 1999; 19: 5902-5912.

46. Davidowitz EJ, Schoenfeld AR, Burk RD. VHL induces renal cell differentiation and growth arrest through integration of cell-cell and cell-extracellular matrix signaling. Mol Cell Biol 2001; 21: 865-874.

47. Bishop T, Lau KW, Epstein AC, Kim SK, Jiang M, O'Rourke D et al. Genetic analysis of pathways regulated by the von Hippel-Lindau tumor suppressor in Caenorhabditis elegans. PLOS Biol 2004; 2: e289.

48. Calzada MJ, Esteban MA, Feijoo-Cuaresma M, Castellanos MC, Naranjo-Suarez S Temes $\mathrm{E}$ et al. von Hippel-Lindau tumor suppressor protein regulates the assembly of intercellular junctions in renal cancer cells through hypoxia-inducible factor-independent mechanisms. Cancer Res 2006; 66: 1553-1560.

49. Yang $H$, Minamishima YA, Yan Q, Schlisio S, Ebert BL, Zhang $X$ et al. pVHL acts as an adaptor to promote the inhibitory phosphorylation of the NF-kappaB agonist Card9 by CK2. Mol Cell 2007; 28: 15-27.

50. Peruzzi B, Athauda G, Bottaro DP. The von Hippel-Lindau tumor suppressor gene product represses oncogenic beta-catenin signaling in renal carcinoma cells. Proc Nat Acad Sci USA 2006; 103: 14531-14536.

51. Roe JS, Kim H, Lee SM, Kim ST, Cho EJ, Youn HD. p53 stabilization and transactivation by a von Hippel-Lindau protein. Mol Cell 2006; 22: 395-405.

52. Hergovich A, Lisztwan J, Barry R, Ballschmieter P, Krek W. Regulation of microtubule stability by the von Hippel-Lindau tumour suppressor protein pVHL. Nat Cell Biol 2003; 5 64-70.

53. Thoma CR, Frew IJ, Hoerner CR, Montani M, Moch H, Krek W. pVHL and GSK3beta are components of a primary cilium-maintenance signalling network. Nat Cell Biol 2007; 9 : 588-595.

54. Schermer B, Ghenoiu C, Bartram M, Muller RU, Kotsis F, Hohne M et al. The von HippelLindau tumor suppressor protein controls ciliogenesis by orienting microtubule growth. J Cell Biol 2006; 175: 547-554

55. Lutz MS, Burk RD. Primary cilium formation requires von Hippel-Lindau gene function in renal-derived cells. Cancer Res 2006; 66: 6903-6907.

56. Zhou MI, Wang H, Foy RL, Ross JJ, Cohen HT. Tumor suppressor von Hippel-Lindau (VHL) stabilization of Jade-1 protein occurs through plant homeodomains and is VHL mutation dependent. Cancer Res 2004; 64: 1278-1286.

57. Zhou MI, Wang H, Ross JJ, Kuzmin I, Xu C, Cohen HT. The von Hippel-Lindau tumo suppressor stabilizes novel plant homeodomain protein Jade-1. J Biol Chem 2002; 277 39887-39898.

58. Pal S, Claffey KP, Dvorak HF, Mukhopadhyay D. The von Hippel-Lindau gene produc inhibits vascular permeability factor/vascular endothelial growth factor expression in renal cell carcinoma by blocking protein kinase C pathways. J Biol Chem 1997; 272 27509-27512.

59. Pal S, Claffey KP, Cohen HT, Mukhopadhyay D. Activation of Sp1-mediated vascular permeability factor/vascular endothelial growth factor transcription requires specific interaction with protein kinase C zeta. J Biol Chem 1998; 273: 26277-26280.

60. Datta K, Nambudripad R, Pal S, Zhou M, Cohen HT, Mukhopadhyay D. Inhibition of insulin-like growth factor-I-mediated cell signaling by the von Hippel-Lindau gene product in renal cancer. J Biol Chem 2000; 275: 20700-20706.

61. Datta K, Sundberg C, Karumanchi SA, Mukhopadhyay D. The 104-123 amino acid sequence of the beta-domain of von Hippel-Lindau gene product is sufficient to inhibit renal tumor growth and invasion. Cancer Res 2001; 61: 1768-1775.

62. Okuda H, Saitoh K, Hirai S, Iwai K, Takaki Y, Baba M et al. The von Hippel-Lindau tumo suppressor protein mediates ubiquitination of activated atypical protein kinase $\mathrm{C}$. J Bio Chem 2001; 276: 43611-43617.

63. Li Z, Wang D, Na X, Schoen SR, Messing EM, Wu G. The VHL protein recruits a nove KRAB-A domain protein to repress HIF-1alpha transcriptional activity. EMBO J 2003; 22 1857-1867.

64. Li Z, Na X, Wang D, Schoen SR, Messing EM, Wu G. Ubiquitination of a nove deubiquitinating enzyme requires direct binding to von Hippel-Lindau tumor suppressor protein. J Biol Chem 2002; 277: 4656-4662.

65. Kuznetsova AV, Meller J, Schnell PO, Nash JA, Ignacak ML, Sanchez Y et al. von HippelLindau protein binds hyperphosphorylated large subunit of RNA polymerase II through a proline hydroxylation motif and targets it for ubiquitination. Proc Natl Acad Sci USA 2003; 100: 2706-2711.

66. Pioli PA, Rigby WF. The von Hippel-Lindau protein interacts with heteronuclea ribonucleoprotein a2 and regulates its expression. J Biol Chem 2001; 276: 40346-40352.

67. Gnarra JR, Ward JM, Porter FD, Wagner JR, Devor DE, Grinberg A et al. Defective placental vasculogenesis causes embryonic lethality in VHL-deficient mice. Proc Nat Acad Sci USA 1997; 94: 9102-9107.

68. Takeda K, Ho VC, Takeda H, Duan LJ, Nagy A, Fong GH. Placental but not heart defects are associated with elevated hypoxia-inducible factor alpha levels in mice lacking proly hydroxylase domain protein 2. Mol Cell Biol 2006; 26: 8336-8346.

69. Pfander D, Kobayashi T, Knight MC, Zelzer E, Chan DA, Olsen BR et al. Deletion of Vhlh in chondrocytes reduces cell proliferation and increases matrix deposition during growth plate development. Development 2004; 131: 2497-2508

70. Schipani E, Ryan HE, Didrickson S, Kobayashi T, Knight M, Johnson RS. Hypoxia in cartilage: HIF-1alpha is essential for chondrocyte growth arrest and survival. Genes Dev 2001; 15: 2865-2876.
71. Neumann HP, Bender BU. Genotype-phenotype correlations in von Hippel-Lindau disease. J Intern Med 1998; 243: 541-545.

72. Clifford SC, Cockman ME, Smallwood AC, Mole DR, Woodward ER, Maxwell PH et al. Contrasting effects on HIF-1alpha regulation by disease-causing pVHL mutations correlate with patterns of tumourigenesis in von Hippel-Lindau disease. Hum Mol Genet 2001; 10: 1029-1038.

73. Hoffman MA, Ohh M, Yang H, Klco JM, Ivan M, Kaelin Jr WG. von Hippel-Lindau protein mutants linked to type $2 \mathrm{C} \mathrm{VHL}$ disease preserve the ability to downregulate HIF. Hum Mol Genet 2001; 10: 1019-1027.

74. Cario H, Schwarz K, Jorch N, Kyank U, Petrides PE, Schneider DT et al. Mutations in the von Hippel-Lindau (VHL) tumor suppressor gene and VHL-haplotype analysis in patients with presumable congenital erythrocytosis. Haematologica 2005; 90: 19-24.

75. Ang SO, Chen H, Hirota K, Gordeuk VR, Jelinek J, Guan Y et al. Disruption of oxygen homeostasis underlies congenital Chuvash polycythemia. Nat Genet 2002; 32: 614-621.

76. Haase VH, Glickman JN, Socolovsky M, Jaenisch R. Vascular tumors in livers with targeted inactivation of the von Hippel-Lindau tumor suppressor. Proc Natl Acad Sci USA 2001; 98: 1583-1588.

77. Rojiani AM, Owen DA, Berry K, Woodhurst B, Anderson FH, Scudamore CH et al. Hepatic hemangioblastoma. An unusual presentation in a patient with von Hippel-Lindau disease. Am J Surg Pathol 1991; 15: 81-86.

78. McGrath FP, Gibney RG, Morris DC, Owen DA, Erb SR. Case report: multiple hepatic and pulmonary haemangioblastomas - a new manifestation of von Hippel-Lindau disease. Clin Radiol 1992; 45: 37-39.

79. Ma W, Tessarollo L, Hong SB, Baba M, Southon E, Back TC et al. Hepatic vascular tumors, angiectasis in multiple organs, and impaired spermatogenesis in mice with conditional inactivation of the VHL gene. Cancer Res 2003; 63: 5320-5328.

80. Ding M, Cui S, Li C, Jothy S, Haase V, Steer BM et al. Loss of the tumor suppressor Vhlh leads to upregulation of $\mathrm{Cxcr} 4$ and rapidly progressive glomerulonephritis in mice. Nat Med 2006; 12: 1081-1087

81. Brukamp K, Jim B, Moeller MJ, Haase VH. Hypoxia and podocyte-specific Vhlh deletion confer risk of glomerular disease. Am J Physiol Renal Physiol 2007; 293: 1397-1407.

82. Steenhard B, Isom K, Stroganova L, St John PL, Freeburg PB, Holzman LB et al. Podocyte-selective deletion of von Hippel-Lindau (VHL) protein causes albuminuria. In: ASN Annual Meeting, 2005, Philadelphia, PA J Am Soc Nephrol 2005: 667A

83. Rankin EB, Tomaszewski JE, Haase VH. Renal cyst development in mice with conditiona inactivation of the von Hippel-Lindau tumor suppressor. Cancer Res 2006; 66: 2576-2583

84. Peyssonnaux C, Zinkernagel AS, Schuepbach RA, Rankin E, Vaulont S, Haase VH et al. Regulation of iron homeostasis by the hypoxia-inducible transcription factors (HIFs) J Clin Invest 2007; 117: 1926-1932.

85. Neumann AK, Yang J, Biju MP, Joseph SK, Johnson RS, Haase VH et al. Hypoxia inducible factor 1 alpha regulates $\mathrm{T}$ cell receptor signal transduction. Proc Natl Acad Sc USA 2005; 102: 17071-17076.

86. Biju MP, Neumann AK, Bensinger SJ, Johnson RS, Turka LA, Haase VH. Vhlh gene deletion induces Hif-1-mediated cell death in thymocytes. Mol Cell Biol 2004; 24 9038-9047.

87. Cramer T, Yamanishi Y, Clausen BE, Forster I, Pawlinski R, Mackman N et al. HIF-1alpha is essential for myeloid cell-mediated inflammation. Cell 2003; 112: 645-657.

88. Karhausen J, Furuta GT, Tomaszewski JE, Johnson RS, Colgan SP, Haase VH. Epithelial hypoxia-inducible factor- 1 is protective in murine experimental colitis. J Clin Invest 2004; 114: 1098-1106.

89. Seagroves TN, Liao D, Cardiff R, Haase VH, Johnson RS. Deletion of vhl impairs norma mammary gland development. In: Biology of Hypoxia: The Role of Oxygen Sensing in Development, Normal Function and Disease. Keystone Symposia: Steamboat Springs, Colorado, 2004, p 100

90. Boutin A, Haase VH, Johnson RS. Response to oxygenation in differentiation, function and pathology of the epidermis. In: Biology of Hypoxia: The Role of Oxygen Sensing in Development, Normal Function and Disease. Keystone Symposia: Steamboat Springs, Colorado, 2004, p 114.

91. Tang N, Mack F, Haase VH, Simon MC, Johnson RS. pVHL function is essential for endothelial extracellular matrix deposition. Mol Cell Biol 2006; 26: 2519-2530.

92. Wang Y, Wan C, Deng L, Liu X, Cao X, Gilbert SR et al. The hypoxia-inducible factor alpha pathway couples angiogenesis to osteogenesis during skeletal development. J Clin Invest 2007; 117: 1616-1626.

93. Hong SB, Furihata M, Baba M, Zbar B, Schmidt LS. Vascular defects and liver damage by the acute inactivation of the VHL gene during mouse embryogenesis. Lab Invest 2006; 86: $664-675$.

94. Vortmeyer AO, Gnarra JR, Emmert-Buck MR, Katz D, Linehan WM, Oldfield EH et al. von Hippel-Lindau gene deletion detected in the stromal cell component of a cerebellar hemangioblastoma associated with von Hippel-Lindau disease. Hum Pathol 1997; 28: 540-543.

95. Lach B, Gregor A, Rippstein P, Omulecka A. Angiogenic histogenesis of stromal cells in hemangioblastoma: ultrastructural and immunohistochemical study. Ultrastruct Patho 1999; 23: 299-310.

96. Vortmeyer AO, Frank S, Jeong SY, Yuan K, Ikejiri B, Lee YS et al. Developmental arrest of angioblastic lineage initiates tumorigenesis in von Hippel-Lindau disease. Cancer Res 2003; 63: 7051-7055 
97. Neumann HP, Zbar B. Renal cysts, renal cancer and von Hippel-Lindau disease [editorial]. Kidney Int 1997; 51: 16-26.

98. Kleymenova E, Everitt JI, Pluta L, Portis M, Gnarra JR, Walker CL. Susceptibility to vascular neoplasms but no increased susceptibility to renal carcinogenesis in Vhl knockout mice. Carcinogenesis 2004; 25: 309-315.

99. Da Silva JL, Lacombe C, Bruneval P, Casadevall N, Leporrier M, Camilleri JP et al. Tumo cells are the site of erythropoietin synthesis in human renal cancers associated with polycythemia. Blood 1990; 75: 577-582.

100. Krieg M, Marti $\mathrm{HH}$, Plate $\mathrm{KH}$. Coexpression of erythropoietin and vascular endothelial growth factor in nervous system tumors associated with von Hippel-Lindau tumor suppressor gene loss of function. Blood 1998; 92: 3388-3393.

101. Hickey MM, Lam JC, Bezman NA, Rathmell WK, Simon MC. von Hippel-Lindau mutation in mice recapitulates Chuvash polycythemia via hypoxia-inducible factor-2alpha signaling and splenic erythropoiesis. J Clin Invest 2007; 117: 3879-3889.

102. Yoder BK. Role of primary cilia in the pathogenesis of polycystic kidney disease. J Am Soc Nephrol 2007; 18: 1381-1388.

103. Esteban MA, Harten SK, Tran MG, Maxwell PH. Formation of primary cilia in the renal epithelium is regulated by the von Hippel-Lindau tumor suppressor protein. J Am Soc Nephrol 2006; 17: 1801-1806.

104. Maher ER, Kaelin Jr WG. von Hippel-Lindau disease. Medicine (Baltimore) 1997; 76 381-391.

105. Mandriota SJ, Turner KJ, Davies DR, Murray PG, Morgan NV, Sowter HM et al. HIF activation identifies early lesions in VHL kidneys: evidence for site-specific tumo suppressor function in the nephron. Cancer Cell 2002; 1: 459-468.

106. Esteban MA, Tran MG, Harten SK, Hill P, Castellanos MC, Chandra A et al. Regulation of E-cadherin expression by VHL and hypoxia-inducible factor. Cancer Res 2006; 66 3567-3575.

107. Evans AJ, Russell RC, Roche O, Burry TN, Fish JE, Chow VW et al. VHL promotes E2 box-dependent E-cadherin transcription by HIF-mediated regulation of SIP1 and snail. Mol Cell Biol 2007; 27: 157-169.

108. Krishnamachary B, Zagzag D, Nagasawa H, Rainey K, Okuyama H, Baek JH et al. Hypoxia-inducible factor-1-dependent repression of E-cadherin in von Hippel-Lindau tumor suppressor-null renal cell carcinoma mediated by TCF3, ZFHX1A, and ZFHX1B. Cancer Res 2006; 66: 2725-2731.

109. Pennacchietti S, Michieli P, Galluzzo M, Mazzone M, Giordano S, Comoglio PM. Hypoxia promotes invasive growth by transcriptional activation of the met protooncogene. Cance Cell 2003; 3: 347-361.

110. Thomas GV, Tran C, Mellinghoff IK, Welsbie DS, Chan E, Fueger B et al. Hypoxiainducible factor determines sensitivity to inhibitors of mTOR in kidney cancer. Nat Med 2006; 12: 122-127

111. Staller P, Sulitkova J, Lisztwan J, Moch H, Oakeley EJ, Krek W. Chemokine recepto CXCR4 downregulated by von Hippel-Lindau tumour suppressor pVHL. Nature 2003 425: 307-311.

112. Gervais ML, Henry PC, Saravanan A, Burry TN, Gallie BL, Jewett MA et al. Nuclear $\mathrm{E}$-cadherin and $\mathrm{VHL}$ immunoreactivity are prognostic indicators of clear-cell renal cell carcinoma. Lab Invest 2007; 87: 1252-1264.

113. Turner KJ, Moore JW, Jones A, Taylor CF, Cuthbert-Heavens D, Han C et al. Expression of hypoxia-inducible factors in human renal cancer: relationship to angiogenesis and to the von Hippel-Lindau gene mutation. Cancer Res 2002; 62 2957-2961.

114. Rosenberger C, Mandriota S, Jurgensen JS, Wiesener MS, Horstrup JH, Frei U et al. Expression of hypoxia-inducible factor-1alpha and -2alpha in hypoxic and ischemic rat kidneys. J Am Soc Nephrol 2002; 13: 1721-1732.

115. Kondo K, KIco JM, Nakamura E, Lechpammer M, Kaelin WG. Inhibition of HIF is necessary for tumor suppression by the von Hippel-Lindau protein. Cancer Cell 2002; 1 237-246.
116. Maranchi JK, Vasselli JR, Riss J, Bonifacio JS, Linehan WM, Klausner RD. The contribution of VHL subtrate binding and HIF-1 $\alpha$ to the phenotype of vhl loss in renal cell carcinoma. Cancer Cell 2002; 1: 247-253.

117. Zimmer M, Doucette D, Siddiqui N, lliopoulos $\mathrm{O}$. Inhibition of hypoxia-inducible factor is sufficient for growth suppression of VHL-/- tumors. Mol Cancer Res 2004; 2: 89-95.

118. Kondo K, Kim WY, Lechpammer M, Kaelin Jr WG. Inhibition of HIF2alpha is sufficient to suppress pVHL-defective tumor growth. PLoS Biol 2003; 1: E83.

119. Smith K, Gunaratnam L, Morley M, Franovic A, Mekhail K, Lee S. Silencing of epidermal growth factor receptor suppresses hypoxia-inducible factor-2-driven $\mathrm{VHL}-/$ - renal cancer. Cancer Res 2005; 65: 5221-5230.

120. Raval RR, Lau KW, Tran MG, Sowter HM, Mandriota SJ, Li JL et al. Contrasting properties of hypoxia-inducible factor 1 (HIF-1) and HIF-2 in von Hippel-Lindauassociated renal cell carcinoma. Mol Cell Biol 2005; 25: 5675-5686.

121. Bindra RS, Vasselli JR, Stearman R, Linehan WM, Klausner RD. VHL-mediated hypoxia regulation of cyclin D1 in renal carcinoma cells. Cancer Res 2002; 62: 3014-3019.

122. Zatyka M, da Silva NF, Clifford SC, Morris MR, Wiesener MS, Eckardt KU et al. Identification of cyclin D1 and other novel targets for the von Hippel-Lindau tumor suppressor gene by expression array analysis and investigation of cyclin D1 genotype as a modifier in von Hippel-Lindau disease. Cancer Res 2002; 62: 3803-3811.

123. Wykoff CC, Sotiriou C, Cockman ME, Ratcliffe PJ, Maxwell P, Liu E et al. Gene array of VHL mutation and hypoxia shows novel hypoxia-induced genes and that cyclin D1 is a VHL target gene. Br J Cancer 2004; 90: 1235-1243.

124. Gordan JD, Bertout JA, Hu CJ, Diehl JA, Simon MC. HIF-2alpha promotes hypoxic cell proliferation by enhancing c-myc transcriptional activity. Cancer Cell 2007; 11: 335-347.

125. Acker T, Diez-Juan A, Aragones J, Tiwa M, Brusselmans K, Moons L et al. Genetic evidence for a tumor suppressor role of HIF-2alpha. Cancer Cell 2005; 8: 131-141.

126. Maynard MA, Evans AJ, Shi W, Kim WY, Liu FF, Ohh M. Dominant-negative HIF-3alpha4 suppresses VHL-null renal cell carcinoma progression. Cell Cycle 2007; 6: 2810-2816.

127. Pollard PJ, Spencer-Dene B, Shukla D, Howarth K, Nye E, El-Bahrawy M et al. Targeted inactivation of fh1 causes proliferative renal cyst development and activation of the hypoxia pathway. Cancer Cell 2007; 11: 311-319.

128. Mack FA, Rathmell WK, Arsham AM, Gnarra J, Keith B, Simon MC. Loss of pVHL is sufficient to cause HIF dysregulation in primary cells but does not promote tumor growth. Cancer Cell 2003; 3: 75-88.

129. Carmeliet $P$, Dor $Y$, Herbert JM, Fukumura D, Brusselmans K, Dewerchin $M$ et al. Role of HIF-1alpha in hypoxia-mediated apoptosis, cell proliferation and tumour angiogenesis. Nature 1998; 394: 485-490.

130. Rathmell WK, Hickey MM, Bezman NA, Chmielecki CA, Carraway NC, Simon MC. In vitro and in vivo models analyzing von Hippel-Lindau disease-specific mutations. Cancer Res 2004; 64: 8595-8603.

131. Hu CJ, Iyer S, Sataur A, Covello KL, Chodosh LA, Simon MC. Differential regulation of the transcriptional activities of hypoxia-inducible factor 1 alpha (HIF-1alpha) and HIF-2alpha in stem cells. Mol Cell Biol 2006; 26: 3514-3526.

132. Flamme I, Krieg M, Plate KH. Up-regulation of vascular endothelial growth factor in stromal cells of hemangioblastomas is correlated with up-regulation of the transcription factor HRF/HIF-2alpha. Am J Pathol 1998; 153: 25-29.

133. Kim WY, Safran M, Buckley MR, Ebert BL, Glickman J, Bosenberg M et al. Failure to prolyl hydroxylate hypoxia-inducible factor alpha phenocopies VHL inactivation in vivo. EMBO J 2006; 25: 4650-4662

134. Takeda K, Cowan A, Fong GH. Essential role for prolyl hydroxylase domain protein 2 in oxygen homeostasis of the adult vascular system. Circulation 2007; 116: 774-781.

135. Berra E, Benizri E, Ginouves A, Volmat V, Roux D, Pouyssegur J. HIF prolyl-hydroxylase 2 is the key oxygen sensor setting low steady-state levels of HIF-1alpha in normoxia. EMBO J 2003; 22: 4082-4090.

136. Appelhoff RJ, Tian YM, Raval RR, Turley H, Harris AL, Pugh CW et al. Differential function of the prolyl hydroxylases PHD1, PHD2, and PHD3 in the regulation of hypoxia-inducible factor. J Biol Chem 2004; 279: 38458-38465. 